\title{
Helminths of the guinea pig, Cavia porcellus (Linnaeus), in Brazil
}

\author{
Roberto Magalhães Pinto 1, 2, 3 \\ Delir Corrêa Gomes ${ }^{1,2}$ \\ Luís C. Muniz-Pereira ${ }^{1}$ \\ Dely Noronha ${ }^{1}$
}

\begin{abstract}
Worm burdens were evaluated and compared in two groups of the guinea pig, Cavia porcellus (Linnaeus, 1758): animals of the first group were conventionally maintained in an institutional animal house and those of the second group were openly kept in pet shops in Brazil. Animals from both sources were infected only with the nematode Paraspidodera uncinata (Rudolphi, 1819) Travassos, 1914 (10\% of prevalence in guinea pigs from the institutional facility and $40 \%$ in those animals from the pet shop). Other helminth samples recovered from Brazilian guinea pigs during 52 years and that are deposited in the Helminthological Collection of the Oswaldo Cruz Institute (CHIOC) were also analyzed. Paraspidodera uncinata and the cestode Monoecocestus parcitesticulatus Rêgo, 1960 were identified in these samples.

KEY WORDS. Helminths, Paraspidodera uncinata, Monoecocestus parcitesticulatus, Cavia porcellus, guinea pig, Brazil
\end{abstract}

Taking into account the concern laboratory and, most recently, pet animals arise worldwide and based on an established program (present authors) scheduled to control the sanitary conditions of different animal houses that supply Brazilian institutions with laboratory animals for scientific research, investigations have been developed in order to provide a reliable survey of the helminth fauna occurring in several animal models, mainly rodents, commonly maintained, but seldom evaluated, considering the few data available regarding the parasites they may harbor. The proper identification of the helminths infecting laboratory animals is necessary, considering that parasites may act as variables, usually unsuspected, in experiments.

Helminths of mice, rats and hamsters from Brazilian animal facilities have been investigated and the present data add new information to previous reports of the helminth fauna of laboratory and pet rodents in Brazil (PINTO et al. 1994, 2001a, b, GONÇALVES et al. 1998).

The present survey is related to nematode parasites of either conventionally maintained or openly kept guinea pigs. An extra amount of helminth (nematode and cestode) samples previously recovered from these hosts in Brazil were also identified and included.

1) Laboratório de Helmintos Parasitos de Vertebrados, Departamento de Helmintologia, Instituto Oswaldo Cruz. Avenida Brasil 4365, 21045-900 Rio de Janeiro, Rio de Janeiro, Brasil.

2) CNPq research fellow.

3) Corresponding author. E-mail: rmpinto@ioc.fiocruz.br

Revta bras. Zool. 19 (Supl. 1): 261 - 269, 2002 


\section{MATERIAL AND METHODS}

Animals. In February 1997 and October/November 2001, adult male specimens of the guinea pig Cavia porcellus (Linnaeus, 1758) were obtained from a pet shop and from an institutional animal house, respectively, in Rio de Janeiro, Brazil. The suppliers were not identified by name, because of ethical reasons. The animals were allocated into groups A (institutional animal house) and B (pet shop) with 20 animals/group. Pet shop guinea pigs were considered as an outside openly kept group, in the comparison of the prevalence of helminths and intensity of parasitism.

Husbandry. Prior to their arrival at the laboratory, the guinea pigs from the institutional animal house (weight 240 to $1,000 \mathrm{~g}$ ) were maintained conventionally in groups of 14 animals ( 06 adults and up to 08 newborn in $90 \times 60 \times 30$ $\mathrm{cm}$ plastic cages with stainless-steel screened covers and daily changed bedding of pine shavings. Animals received ad libitum Nuvital $^{\circledR}$ pellets (PR 145300104, Ministry of Agriculture, Brazil)) and filtered water with ascorbic acid from nursing bottles adapted to the covers. Bedding and chow were sterilized (heated for $20 \mathrm{~min}$ at $121^{\circ} \mathrm{C}$ ) only for animals of group A. The temperature of the animal room was maintained at $20-22^{\circ} \mathrm{C}$. Guinea pigs from the institutional animal facility were not submitted to anthelmintics and their microbiological status was not specified. Housing was in accord to Brazilian guidelines for the care and use of laboratory animals (APA 1989). The guinea pigs from the pet shop (weight, 200 to $450 \mathrm{~g}$ ), openly maintained at room temperature $\left(25-38^{\circ} \mathrm{C}\right)$, were kept together in $95.0 \times 51.0 \times 35.0 \mathrm{~cm}$ plastic cages similar to those used in the animal house. They received ad libitum Labina ${ }^{\circledR}$ pellets (Agribands Purina do Brasil Ltd) and untreated water from glass containers on the bottom of the cage.

Parasites. Immediately after their arrival at the laboratory, guinea pigs were sacrificed in an ether chamber according to the Brazilian Code of Ethics for Animals (APA 1989). The development of the present protocol has been authorized by the Committee of Ethics for the Use of Animals (CEUA-FIOCRUZ), no. P0072-01. Nematodes from animals of group A (04 larvae), and from group B (95 adults, 11 larvae), were recovered in a $0.85 \% \mathrm{NaCl}$ solution, fixed in hot $10 \%$ formaldehyde and deposited either as wet material or whole mounts in the Helminthological Collection of the Oswaldo Cruz Institute (CHIOC). Other 18 samples, nine of nematodes and nine of cestodes, previously deposited in the $\mathrm{CHIOC}$, also preserved either as wet material or whole mounts and obtained from Brazilian wild guinea pigs captured from 1914 to 1966 were also considered here. Although cestodes have not been found parasitizing the presently investigated $C$. porcellus of groups A and B, samples of $M$. parcitesticulatus Rêgo, 1960, presumably recovered from Brazilian wild guinea pigs (data on the source of capture is unavailable) and deposited in the CHIOC were reexamined and included in this survey. Additional morphometric data on the species and photomicrographs were also obtained, so to accomplish the early accounts of RÊGO $(1960,1961)$. The procedures for processing of helminths (wet material) for study have been reported elsewhere (PINTO et al. 1994). En face slides were prepared 
by using jelly mounts, in accordance with ANDERSON (1958). Classification of helminths follows FreitAs (1956), CHABAUD (1978) for the nematodes, BEVERIDGE (1994) and JONES et al. (1994) for the cestodes and systematics of the host is in accordance with WoODS (1984). The ecological terms (prevalence, intensity and mean intensity) are used according to BUSH et al. (1997). Photomicrographs derived from a Axiophot microphotographic system (Zeiss, Germany) using T400 CN film (Kodak, Mexico) in a Differential Interference Contrast (DIC) apparatus. Measurements are in micrometers $(\mu \mathrm{m})$ unless otherwise indicated. Means are in parentheses.

\section{RESULTS}

\section{Paraspidodera uncinata (Rudolphi, 1819) Travassos, 1914 Figs 1-7}

Heterakoidea, Aspidoderidae, Lauroriinae. Morphometrics based on 10 adult (05 males, 05 females) and 05 larval specimens recovered from the pet shop animals. Morphological differences were not observed among the samples from the two investigated sources.

Larvae. Body 2.0-5.2 (3.53) mm long, 70-130 (98.4) wide.

Adult males. Body 10.8-11.5 (11.1) mm long, 190-230 (205.4) wide. Esophagus 910-980 (940.6) long. Nerve ring and excretory pore 560-630 (610.8) and 200-300 (253) from anterior extremity, respectively. Spicules subequal, 580-602 (593.6) long. Gubernaculum 120-126 (122.8) long. Ventral sucker 90-100 (94.6) in diameter. Fourteen to 21 pairs of caudal papillae. Cloacal aperture 260-294 (262.2) from posterior extremity.

Adult females. Body 15.0-20.0 (17.4) mm long, 378-402 (391.6) wide. Esophagus 1.05-1.22 (1.14) mm long. Nerve ring and excretory pore 504-620 (612) and 376-410 (394.8) from anterior extremity, respectively. Vulvar aperture 680-800 (734.2) from anterior end. Eggs 40-50 (44.6) long, 30-36 (33.4) wide. Measurements based on ten eggs. Anus 560-700 (628.4) from posterior extremity.

Host. Cavia porcellus - Rodentia, Hystricognathi, Caviidae, Caviinae; common names: guinea pig, "porquinho-da-Índia, preá, cobaio".

Localities. Rio de Janeiro, State of Rio de Janeiro; São Paulo, State of São Paulo, Brazil.

Specimens deposited. CHIOC no. 14, 1824, 4449, 4630, 5665, 7526, 9859 , 30134, wet material; 30083 a-d, whole mounts (deposited between 1914-1966); 34413-34420, 34440, 34441, wet material; 34339 a-g, 34535, whole mounts.

For Paraspidodera uncinata, the prevalence, intensity of infection and mean intensity were of $10 \%, 1-4$ and 0.2 , respectively, in animals of group A (institutional facility) and of 40\%, 1-37 and 5.3, respectively, in animals of group B (pet shop).

Regarding barriers to infection, the practices of the animal house, particularly of sterilizing bedding and chow proved to be relatively effective against $P$. uncinata, considering the low worm burdens infecting the animals of group A. 

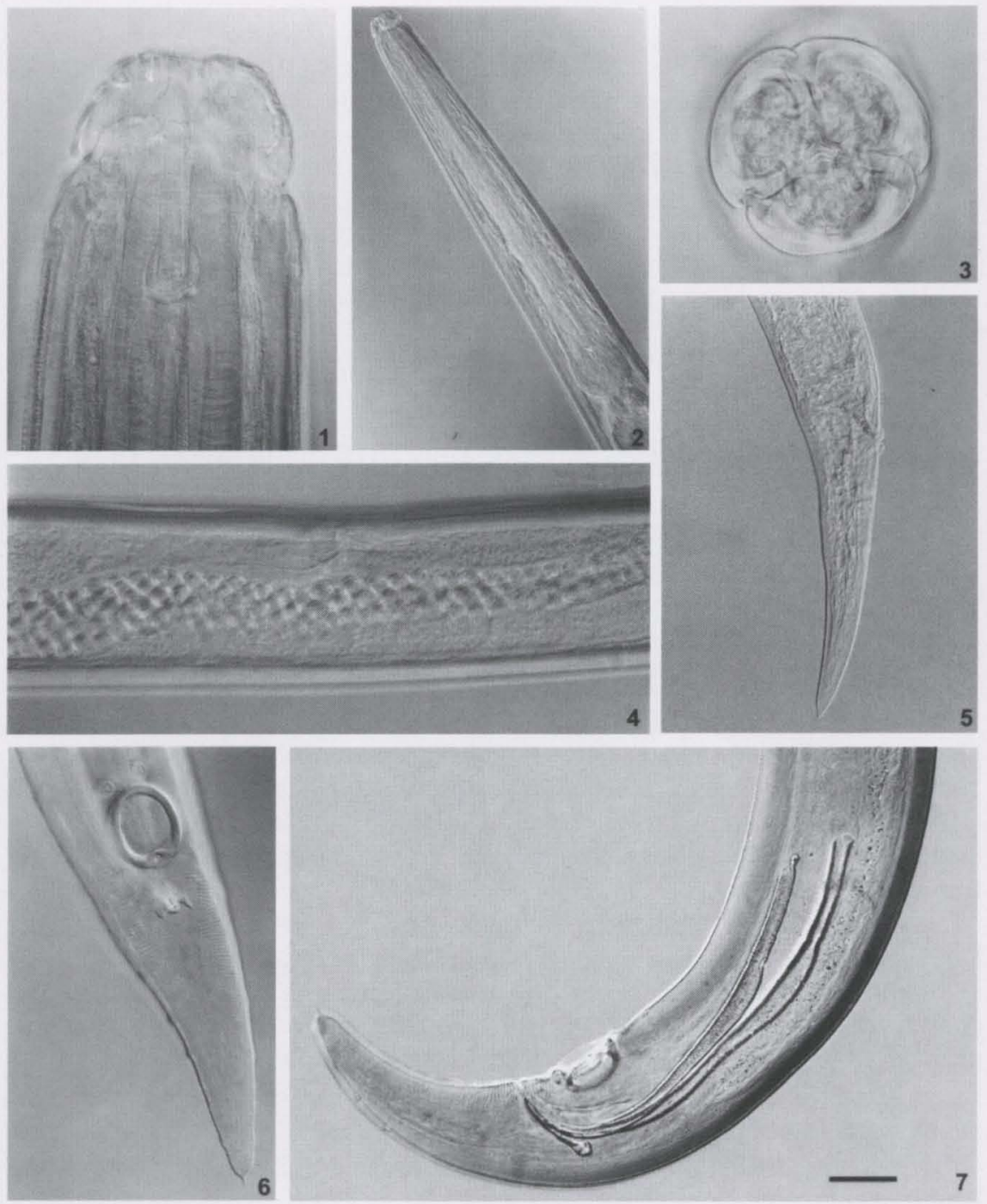

Figs 1-7. Paraspidodera uncinata. (1) Anterior extremity of the male, lateral view, bar $=0.05$ $\mathrm{mm}$; (2) anterior extremity of the larva, lateral view, bar $=0.1 \mathrm{~mm}$; (3) cephalic extremity of the female, en face view, bar $=0.02 \mathrm{~mm}$; (4) vulvar region and ovejector, bar $=0.1 \mathrm{~mm}$; (5) posterior extremity of the larva, lateral view, bar $=0.6 \mathrm{~mm} ;(6)$ posterior extremity of the male, ventral view, bar = $1 \mathrm{~mm}$; (7) posterior extremity of the male, lateral view, bar $=1 \mathrm{~mm}$. Bar of figure 7 , common to figures 1-6.

Larvae of $P$. uncinata are very rare in feces of guinea pigs, and the modified anal swab device that was used (GONÇALVES et al. 1998) to detect eggs, failed to show the presence of larvae. Therefore, there was the need to sacrifice animals of both groups investigated herein. 


\title{
Monoecocestus parcitesticulatus Rêgo, 1960
}

\author{
Figs 8-11
}

Cyclophyllidea, Anoplocephalidae, Anoplocephalinae. Morphometrics (based on 11 specimens): strobila small to large. Proglottids craspedote, wider than long. Scolex without rostelum 250-514 (490) x 390-597 (585), suckers unarmed, 108-226 (210) in diameter. Genital pores alternate regularly. Mature proglottids 210-250 (226) long, 910-980 (938) wide. Gravid proglottids $0.369-0.435$ (0.411) long, 1.77-2.51 (2.21) $\mathrm{mm}$ wide. Thirty to fifty testes, posterior to ovary, distributed in bands, 43-52 (47) in diameter. Cirrus pouch 320-380 (352) long; internal and external seminal vesicle present. Ovary multilobed 763-830 (811) wide. Vagina opens to genital atrium anterior to cirrus pouch. Uterus reticulate. Eggs, pyriform apparatus and embryo, 40-51 (47), 12-14 (13) and 25-28 (26) in diameter, respectively.

Host. Cavia porcellus.

Localities. Rio de Janeiro and Conceição de Macabú, State of Rio de Janeiro, Araçatuba, State of São Paulo, Brazil.

Specimens deposited. CHIOC no.1822, 5680,17766, 28133, wet material; 4401 (type), 27715 a-b, 27716, 27717 a-d, 27718 a-b, whole mounts (deposited between 1914-1960); 34371 a-d, whole mounts derived from the sample no. 28133.

\section{REMARKS}

Paraspidodera uncinata - in a brief account, $P$. uncinata was described by RUDOLPHI (1819) as Ascaris uncinata on the basis of Brazilian material from Cavia porcellus and was referred to as Heterakis uncinata by SCHNEIDER (1866) and TRAVASSOS (1913).

TRAVASSOS (1914) proposed the genus Paraspidodera to include $P$. uncinata as the type and only species of the new erected genus for nematodes recovered from the cecum and large intestine of the guinea pig Cavia porcellus, $C$. aperea Erxleben, 1777 and the paca Agouti paca (Linnaeus, 1776).

The species was redescribed and figured by PEREIRA \& VAZ (1933) on the basis of specimens parasitizing guinea pigs (C. porcellus) conventionally maintained in laboratory.

VICENTE et al. (1997) refer to Paraspidodera uncinata, Gongylonema neoplasticum (Fibiger \& Ditlevsen, 1917) and Hyostrongylus rubidus (Hassal, 1829) occurring naturally in Cavia porcellus; nevertheless, the two latter species were neither represented in the samples of the present investigation nor in those previously deposited in the CHIOC and also studied here.

Even during early investigations, authors (PEREIRA \& VAZ 1933) showed to be already concerned with the accuracy of the results derived from experimental assays in which guinea pigs naturally infected with $P$. uncinata were utilized and with the possible effect of undetected worm burdens on the course of the experiments.

PORTER \& OTTO (1934) in a brief note, reported to heavy natural infections due to Paraspidodera uncinata in laboratory guinea pigs and verified that male animals had heavier infections than did the females. In the experiment, they succeed in feeding naive guinea pigs with embryonated eggs for further recovery of adult worms.

Revta bras. Zool. 19 (Supl. 1): 261 - 269, 2002 

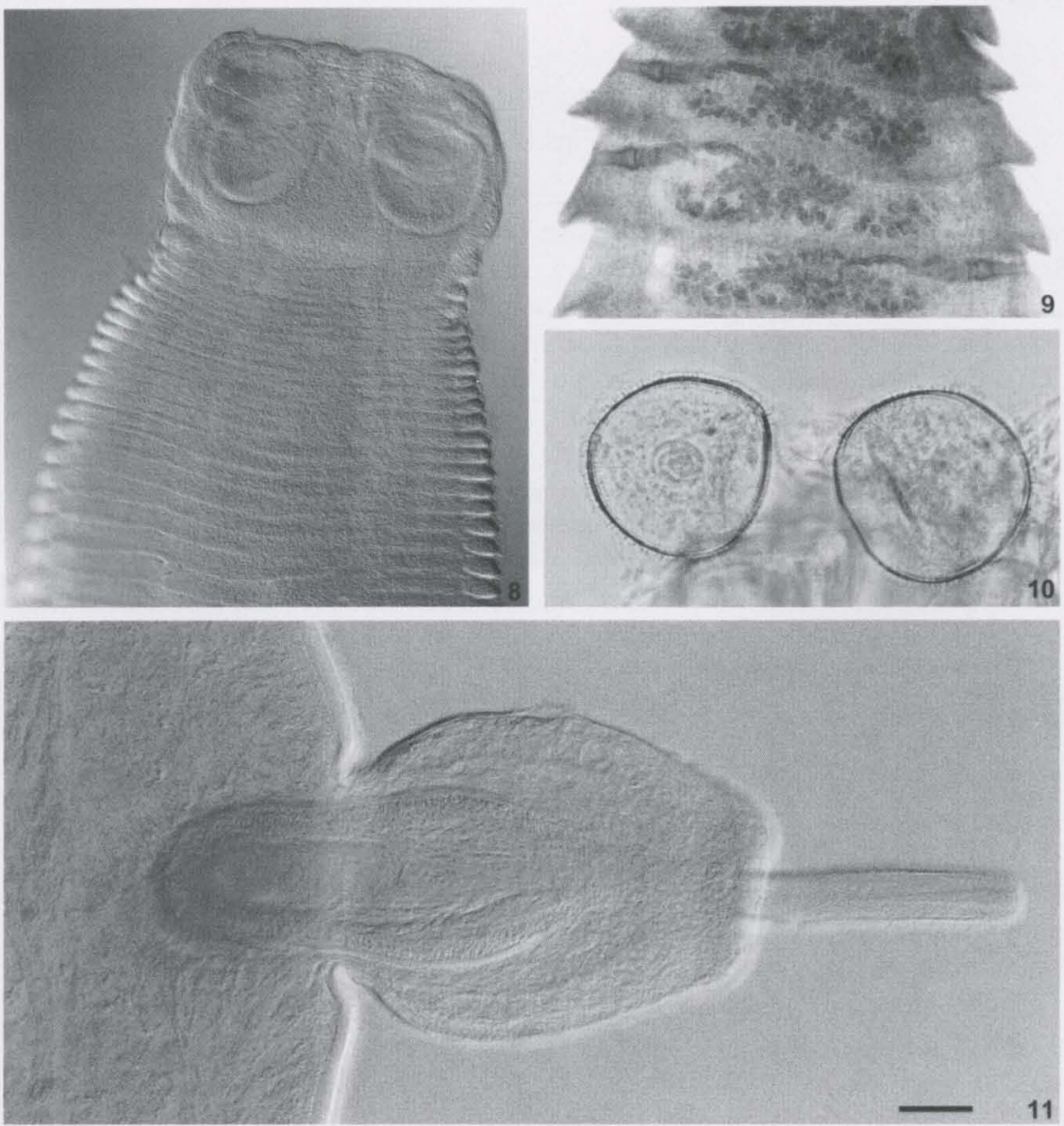

Figs 8-11. Monoecocestus parcitesticulatus. (8) Scolex, bar $=0.1 \mathrm{~mm}$; (9) mature proglottids, bar $=0.1 \mathrm{~mm} ;(10)$ detail of eggs in a gravid proglottid, bar $=0.01 \mathrm{~mm} ;(11)$ detail of the cirrus pouch showing extroverted spined cirrus, bar $=0.04 \mathrm{~mm}$. Bar of figure 11, common to figures 8-10.

The first anthelmintic trials against $P$. uncinata in guinea pigs were developed by HERLICH (1959). Results showed that the three drugs utilized in those trials were ineffective and indicated that this host-parasite system was not satisfactory for screening anthelmintics. Data on the length of the nematodes, recovered from the medicated animals, were included.

HERLICH \& DIXON (1965) again utilizing guinea pigs in experimental assays, made some other observations on the growth and development of $P$. uncinata, that presents a monoxenous life cycle.

BONDY (1966), unaware of the previous results of HERLICH \& DIXON (1965), affirmed to be the first to report data on the life cycle of $P$. uncinata, recovered from C. porcellus, during studies of the morphology, development of eggs and their resistance to dissection under different laboratory conditions. 
CONDER et al. (1989), confirming the hypothesis of PEREIRA \& VAZ (1933), reported to bronchoalveolar eosinophilia in guinea pigs naturally infected with $P$. uncinata. It was suggested that $P$. uncinata is capable of causing changes in inflammatory cell populations in the lungs of guinea pigs, even when animals appear clinically normal, reinforcing the significance of subclinical or inapparent infections in experimental design and interpretation.

BETKE et al. (1982) referred to the early observations of HERLICH (1959) and reported data on the morphology and biology of $P$. uncinata with a preliminary treatment trial, when two anthelmintics were administered and had their effectiveness evaluated in guinea pigs infected with $P$. uncinata. One of the tested drugs proved to be effective against the parasite. Authors reproduced figures after TRAVASSOS (1914).

Monoecocestus parcitesticculatus - On what concerns to the studied cestode species, RÊGO (1960) proposed $M$. parcitesticulatus on the basis of a couple of cestodes parasitizing the guinea pigs Cavia porcellus and C. aperea in Brazil. RÊGO (1961) redescribed and figured the species based on a greater number of samples, adding new morphometric data to the previous description.

In a survey of Brazilian cestodes (TRAVASSOS 1965), the species was only listed among other parasitizing rodent hosts and $M$. parcitesticulatus was not referred again in $C$. porcellus ever since.

According to FREEMAN (1952) Monoecocestus spp. have a heteroxenous life cycle and oribatid mites are the intermediate vectors.

The importance of the report of the helminth fauna also in pet animals is based on the fact that several helminth and protozoal zoonoses are associated with typical companion animals, that are dogs and cats. However, households, owning less traditional pets such as guinea pigs, hamsters and gerbils, have become most usual, propitiating the spreading of uncommon helminth zoonoses (MCCARTHY \& MOORE 2000; ROBERTSON et al. 2000; PINTO et al. 2001a). Most important of all is the fact that data on parasites recovered from laboratory animals can be used as a reliable parameter in the evaluation of the sanitary conditions under which the animals are maintained considering the important role these hosts play in scientific research.

ACKNOWLEDGEMENTS. To the institution which supplied the guinea pigs, to the Setor de Multimeios, Fiocruz and to Heloísa Maria Nogueira Diniz from the Laboratório de Imagens, Instituto Oswaldo Cruz, for technical assistance regarding figures.

\section{REFERENCES}

Anderson, R.C. 1958. Méthod pour l'examen des nématodes en vue apicale. Ann. Par., Paris, 33: 171-172.

APA. 1989. Código de Ética Experimental com Animais. Rio de Janeiro, Sozed, 8p.

BetKe, P.; S. NiCKel \& A. WiLHelm. 1982. Untersuchungen zu Paraspidodera uncinata (Nematoda, Heterakidae), einem Blinddarmparasiten von Cavia porcellus. Angew. Parasitol., Berlin, 23: 197-202.

BeverIDGE, I. 1994. Family Anoplocephalidae Cholodkovsky, 1902, p. 315-366. In: L.F. KHALIL; A. Jones \& R.A. Bray (Eds). Keys to the Cestode Parasites of Vertebrates. Oxon, CAB International, XIII+751p. 
Bondy, R. 1966. Contribution to the knowledge of the exogenic phase of the nematode Paraspidodera uncinata (Rudolphi, 1819). Helminthologia, Kosice, 7: 21-27.

Bush A.O., K.D. LAFFeRTY, J.M. LotZ \& A.W. ShostaK. 1997. Parasitology meets ecology on its own terms: Margolis et al. revisited. Jour. Parasitol., Lawrence, 83: 575-583.

CHABAUd, A.G. 1978. Keys to the genera of the superfamily Cosmocercoidea, Seuratoidea, Heterakoidea and Subuluroidea p. 1-71. In: R.C. Anderson; A.G. Chabaud \& S. Willmott (Eds). CIH Keys to the Nematode Parasites of Vertebrates 6. England, Commonwealth Agricultural Bureaux, Farnham Royal Bucks.

Conder, G.A.; I.M. Richards; L-W. Jen; K.S. Marbury \& J.A. Oostveen. 1989. Brochoalveolar eosinophilia in guinea pigs harboring inapparent infections of Paraspidodera uncinata. Jour. Parasitol., Lawrence, 75: 144-146.

Freeman, R.S. 1952. The biology and life history of Monoecocestus Beddard, 1914 (Cestoda Anoplocephalidae) from the porcupine. Jour. Parasitol., Lawrence, 38: 111-129.

FreITAS, J.F.T. 1956. Notas sobre "Heterakidae" Railliet \& Henry, 1914 (Nematoda, Subuluroidea). Rev. Brasil. Biol., Rio de Janeiro, 16: 461-482.

Gonçalves, L.; R.M. Pinto; J.J. Vicente; D. Noronha \& D.C. Gomes. 1998. Helminth parasites of conventionally maintained laboratory mice - II. Inbred strains with an adaptation of the anal swab technique. Mem. Inst. Oswaldo Cruz, Rio de Janeiro, 93: 121-126.

HERLICH, H. 1959. Anthelmintic trials against Paraspidodera uncinata the cecal worm of the guinea pig, with observations on the length of the nematodes. Jour. Parasitol., Lawrence, 45/46: 586.

HERLICH, H. \& C.F. Dixon. 1965. Growth and development of Paraspidodera uncinata, the cecal worm of the guinea pig. Jour. Parasitol., Lawrence, 51: 300.

Jones, A.; R.A. BRAY \& L.F. KhaliL. 1994. Order Cyclophyllidea van Beneden in Braun, 1900, p. 305-307. In: L.F. Khalil; A. Jones \& R.A. Bray (Eds). Keys to the Cestode Parasites of Vertebrates. CAB International, Oxon, XIII+751p.

McCarthy, J. \& T.A. Moore. 2000. Emerging helminth zoonoses. Int. Jour. Parasitol., Oxford, 30: 1351-1360.

PereiRA, C. \& Z. VAZ. 1933. Nota sobre a presença de Paraspidodera uncinata, em cobayas de São Paulo. Rev. Biol. Hyg., São Paulo, 2: 52-55.

Pinto, R.M.; J.J. Vicente; D. NoRonha; L. GonçAlVEes \& D.C. GoMES. 1994. Helminth parasites of conventionally maintained laboratory mice. Mem. Inst. Oswaldo Cruz, Rio de Janeiro, 89: 33-40.

Pinto, R.M.; L. Gonçalves; D.C. Gomes \& D. Noronha. 2001a. Helminth fauna of the golden hamster Mesocricetus auratus in Brazil. Contemp. Top. Lab. Anim. Sci., Illinois, 40: 20-25.

Pinto, R.M.; L. GonçALVES; D. NoRonha \& D.C. Gomes. 2001b. Worm burdens in outbred and inbred laboratory rats with morphometric data on Syphacia muris (Yamaguti, 1935) Yamaguti, 1941 (Nematoda, Oxyuroidea). Mem. Inst. Oswaldo Cruz, Rio de Janeiro, 96: 133-136.

Porter, D.A. \& G.F. OTto. 1934. The guinea-pig nematode, Paraspidodera uncinata. Jour. Parasitol., Lawrence, 20: 323.

RÊGO, A.A. 1960. Nota prévia sobre uma nova espécie do gênero Monoecocestus Beddard, 1914 (Cestoda, Cyclophyllidea), Atas Soc. Biol. Rio de Janeiro, Rio de Janeiro, 5: 67-68.

- 1961. Revisão do gênero Monoecocestus Beddard, 1914 (Cestoda, Anoplocephalidae. Mem. Inst. Oswaldo Cruz, Rio de Janeiro, 59: 325-354.

RoberTSON, L.D.; P.J. IRWIN; A.J. LYMBERY \& R.C.A. THOMPSON. 2000. The role of companion animals in the emergence of parasitic zoonoses. Int. Jour. Parasitol., Oxford, 30: 1369-1377.

RudolphI, C.A. 1819. Entozoorum Synopsis cui Accedunt Mantissa Duplex et Indices Locupretissimi. Berolini, $\mathrm{X}+811 \mathrm{p}$.

SCHNEIDER, A.F. 1866. Monographie der Nematoden. Berlin, XIII+357p.

TRAvassos, L. 1913. Sobre as especies brazileiras da subfamilia Heterakinae Railliet \& Henry. Mem. Inst. Oswaldo Cruz, Rio de Janeiro, 5: 271-318.

- 1914. Contribuição para o conhecimento da fauna helmintolojica brazileira. Mem. Inst. Oswaldo Cruz, Rio de Janeiro, 6: 137-142. 
1965. Contribuição para o inventário crítico da Zoologia no Brasil. Fauna helmintológica: considerações preliminares - cestódeos. Publ. Avuls Mus. Nac., Rio de Janeiro, 50: 1-84.

Vicente, J. J.; H.O. Rodrigues; D.C. Gomes \& R.M. Pinto. 1997. Nematóides do Brasil. Parte V: Nematóides de Mamíferos. Revta bras. Zool., Curitiba, 14 (Supl. 1): 1-452.

Woods, C.A. 1984. Suborder Hystricognathi, p. 771-806. In: D.E. WiLson \& D.A.M. ReEDER (Eds). Mammal Species of the World. Washington, DC, Smithsonian Institution Press, XVII+1206p.

Received in 11.1.2002; accepted in 01.VII.2002. 